\title{
HUBUNGAN ANTARA KREATIVITAS GURU DENGAN MINAT BELAJAR SISWA DI SEKOLAH DASAR
}

\author{
Latri Aras ${ }^{1}$, Satriani DH ${ }^{2}$, Muhammad Amran ${ }^{3}$, Nabilah Adz Dzikru ${ }^{4}$ \\ 1,2,3,4 Universitas Negeri Makasar \\ Email: latri@gmail.com \\ Email: Satriani.dh@gmail.com \\ Email: neysaamran@gmail.com \\ Email: nabilahadzdzikru@gmail.com
}

\begin{abstract}
Abstrak
Masalah dalam penelitian ini adalah kurangnya kreativitas guru terhadap proses pembelajaran di kelas sehinga membuat siswa kurang memiliki minat belajar. Penelitian ini adalah penelitian kuantitatif dengan jenis penelitian korelasional yang bertujuan untuk mengetahui hubungan kreativitas guru dengan minat belajar siswa. Hasil Penelitian menunjukkan bahwa diperoleh rx $=0,443$ maka hubungan kedua variabel tergolong pada tingkat hubungan dalam kategori "sedang", karena berada pada rentang 0,40 - 0,599 dan nilai $r_{\text {hitung }}(0,443)$ lebih besar $(>)$ nilai $r_{\text {tabel }}(0,177)$ yang berarti $\mathrm{H}_{0}$ ditolak dan $\mathrm{H}_{\mathrm{a}}$ diterima. Berdasarkan dari analisis data di atas dapat disimpulkan kreativitas guru akan berdampak terhadap minat belajar siswa. Jadi, semakin baik kreativitas guru maka akan meningkatkan minat belajar siswa. Dari kesimpulan tersebut, maka dampak yang dihasilkan dari penelitian ini diketahui bahwa kreativitas guru yang baik akan meningkatkan minat belajar siswa.
\end{abstract}

Kata kunci: Kreativitas Guru; Minat Belajar; Siswa

\section{Abstract}

Abstract; The problem in this study is the teacher's lack of creativity in the learning process in the classroom so that students lack interest in learning. This research is a quantitative research with the type of correlational research which aims to determine the relationship between teacher creativity and student interest in learning. The results showed that obtained $r x=0.443$, the relationship between the two variables was classified at the level of relationship in the "medium" category, because it was in the range 0.40 - 0.599 and the rcount value $(0.443)$ was greater $(>)$ rtable value $(0.177)$, which means $\mathrm{HO}$ rejected and $\mathrm{Ha}$ accepted. Based on the analysis of the data above, it can be concluded that teacher creativity will have an impact on students' interest in learning. So, the better the teacher's creativity, the better the student's interest in learning. From these conclusions, the impact resulting from this study is known that the creativity of a good teacher will increase students' interest in learning.

Keywords: Teacher Creativity; Interest to learn; Student

\section{Pendahuluan}

Pendidikan adalah suatu proses
yang dilakukan oleh suatu negara
sebagai upaya mempersiapkan sumber
daya manusia yang memiliki keahlian,
keterampilan dan kreativitas.
Pembangunan suatu bangsa untuk

mencetak sumber daya manusia berkualitas tentunya dipengaruhi oleh mutu pendidikan. Hal ini sejalan dengan isi Undang-Undang Nomor 20 Tahun 2003 tentang Sistem Pendidikan Nasional Bab II Pasal 3, menyatakan bahwa pendidikan nasional berfungsi 
mengembangkan kemampuan dan sebagai salah satu tenaga profesional membentuk watak serta peradaban sebagai pendidik. Berdasarkan Undangbangsa yang bermartabat dalam rangka Undang Guru dan Dosen No.14 Tahun mencerdaskan kehidupan bangsa, 2005 Pasal 2, mengungkapkan bahwa bertujuan untuk berkembangnya potensi guru merupakan tenaga profesional yang peserta didik agar menjadi manusia yang beriman dan bertakwa kepada Tuhan Yang Maha Esa, berakhlak mulia, sehat, berilmu, cakap, kreatif, mandiri, dan menjadi warga Negara demokratis, serta bertanggung jawab.

Mencermati tujuan pendidikan di atas, upaya peningkatan mutu pendidikan dapat tercapai secara optimal, apabila dilakukan perbaikan terhadap komponen pendidikan yang meliputi guru, siswa, dan proses pembelajaran. Pendidikan yang berkualitas ditentukan oleh banyak faktor adalah faktor guru. Guru selaku komponen pendidikan diharapkan dapat mencapai salah satu tujuan pendidikan dalam Undang-Undang Nomor 20 Tahun 2003 untuk berilmu, cakap, kreatif, dan mandiri dalam suatu proses pembelajaran.

Salah satu upaya meningkatkan mutu pendidikan dengan membangun guru kreatif, yaitu kreatif dalam merencanakan program pembelajaran, pelaksanaan proses pembelajaran, kreatif dalam evaluasi siswa, serta pengawasan terhadap siswa yang bermasalah (Aldizar 2017). Guru dikenal tugasnya mendidik dan mengajar dengan persyaratan harus mempunyai kualifikasi akademik, kompetensi, dan sertifikasi pendidik untuk setiap jenis dan jenjang pendidikan tertentu (Suprihatiningrum, 2014, h.24). Artinya, guru yang memiliki keahlian dan kualifikasi harus sesuai dengan syarat-syarat tertentu untuk dapat melaksanakan kegiatan pembelajaran di kelas pada bidang akademik.

Guru merupakan tenaga profesional yang memiliki keahlian dan kualifikasi untuk melaksanakan tugasnya dalam mendidik, mengajar, membimbing, mengarahkan melatih, menilai, dan mengevaluasi siswa. Definisi semakna juga dikemukakan oleh Arifi, Sabarudin, dan Machali (2017) bahwa profesi guru adalah "sebuah pernyataan pengabdian seseorang yang memiliki keahlian di bidang pendidikan dan bersedia mengabdikan dirinya kepada masyarakat demi terwujudnya sistem pendidikan yang sistematis dan pembangunan karakter bangsa kearah yang positif' (h.200). Oleh karena itu, profesi guru bertanggung jawab atas pekerjaannya terhadap proses pembelajaran agar pelaksanaan 
pembelajaran berjalan sesuai dengan tujuan pembelajaran.

Berdasarkan kondisi yang terinspirasi pada kegiatan PPL di SDN 200 Tempe Kabupaten Wajo pada tanggal 01 Oktober - 10 Desember 2021, peneliti menemukan indikasi yang menunjukkan kurangnya minat belajar siswa di sekolah. Gejala tersebut umum terjadi hampir seluruh sekolah di Sulawesi selatan termasuk di Kabupaten Bone. Hal tersebut sejalan dengan wawancara tidak terstruktur yang dilakukan oleh peneliti pada tanggal 2728 April 2021 dengan guru dan siswa dari beberapa sekolah yang termasuk dalam SD Gugus III Kecamatan Tanete Riattang Kabupaten Bone bahwa dalam pembelajaran siswa tampak kurang tertarik untuk mengikuti pelajaran di kelas, karena ada beberapa guru dalam mengajar tidak memberikan penjelasan mengenai materi terlebih dahulu, hanya memberikan tugas saja, dan tidak menggunakan media pembelajaran.

Sehingga siswa tampak kurang tertarik dalam belajar, hal ini pula ditandai dengan sikap siswa yang sering mengeluh apabila diberikan tugas, proses pembelajaran hanya terjadi satu arah dan siswa sering mengumpulkan tugas melebihi batas waktu atau mengumpulkan tugas di akhir batas yang ditentukan. Sikap-sikap siswa tersebut, tercermin pada saat mengikuti proses belajar mengajar di kelas yang tampak kurang tertarik mengikuti pembelajaran.

Ada beberapa penelitian terdahulu yang mengkaji tentang kreativitas guru terhadap minat belajar siswa. Seperti penelitian yang dilakukan oleh Nurhaeda (2020) yang mengkaji tentang pengaruh kreativitas guru dan minat belajar terhadap hail belajar pada mata pelajaran IPS. Hasil penelitian menunjukkan adanya pengaruh yang signifikan antara kreativitas guru dan didukung minat belajar siswa yang tinggi, maka hasil belajar siswa pun akan meningkat tinggi. Penelitian serupa juga dilakukan oleh Nimury (2019) yang mengkaji tentang pengaruh kreativitas guru terhadap minat belajar siswa pada mata pelajaran ekonomi. Hasil penelitian ini menunjukkan bahwa terdapat pengaruh yang signifikan antara kreativitas guru terhadap minat belajar siswa.

Berdasarkan latar belakang masalah, maka rumusan masalah dalam penelitian adalah untuk mengetahui gambaran kreativitas guru dan minat belajar siswa, serta untuk mengetahui ada tidaknya hubungan yang signifikan antara kreativitas guru dan minat belajar siswa dengan judul penelitian "Hubungan antara Kreativitas Guru dengan Minat 
Belajar Siswa kelas V SD Gugus III Kecamatan Tanete Riattang Kabupaten Bone".

Berdasarkan pendapat yang telah diuraikan, maka dapat dikemukakan bahwa kreativitas guru merupakan faktor yang berpengaruh terhadap minat belajar siswa. Oleh karena itu, peneliti tertarik untuk melakukan penelitian mengenai hubungan antara kreativitas guru dengan minat belajar siswa Kelas V Gugus III Kecamatan Tanette Riattang Kabupaten Bone.

\section{Metode Penelitian}

Penelitian ini menggunakan penelitian kuantitatif dengan model korelasional.

Penelitian

korelasional adalah suatu penelitian untuk mencari hubungan antara dua variabel atau lebih yang tidak terdapat manipulasi pada variabel. Penelitian ini bertujuan untuk mengetahui sebab dan akibat. Menurut Sugiyono (2020) "Penelitian Korelasional merupakan penelitian yang dimaksudkan untuk mengetahui ada tidaknya hubungan antara dua atau beberapa variabel" ( $h$. 313).

Penelitian dilaksanakan di sekolah dasar gugus III Kecamatan Tanete Riattang Kabupaten Bone yang berjumlah 8 sekolah. Penelitian ini dilaksanakan pada semester II tahun ajaran 2020/2021. Penelitian dimulai pada bulan Juni dan berakhir pada bulan Juli 2021.

Teknik pengumpulan data yang dilakukan dalam penelitian ini ada dua cara yaitu angket dan dokumentasi. Angket dalam penelitian ini untuk mengumpulkan dan memperoleh data dan informasi mengenai kreativitas guru dan minat belajar. Dalam penelitian ini menggunakan angket dalam bentuk skala likert. Menurut Sugiyono (2020) "skala Likert digunakan untuk mengukur sikap, pendapat, dan persepsi seseorang atau sekelompok orang tentang fenomena sosial. Dalam penelitian, fenomena sosial ini telah ditetapkan secara spesifik oleh peneliti, yang selanjutnya disebut sebagai variabel penelitian" (h. 146). Dengan skala likert, variabel yang akan diukur, dijabarkan menjadi indikator variabel. Kemudian indikator tersebut dijadikan sebagai titik tolak untuk menyusun itemitem instrumen yang dapat berupa pernyataan atau pertanyaan. Teknik dokumentasi yaitu cara mengumpulkan dan memperoleh data mengenai jumlah siswa kelas V SD Gugus III Kecamatan Tanete Riattang Kabupaten Bone.

\section{Hasil dan Pembahasan}

Harapan yang ada pada setiap guru adalah bagaimana siswa dapat 
memahami dengan baik materi yang disampaikan. Oleh, karena itu guru dituntut mengembangkan kemampuan pelaksanaan pembelajaran yang kreatif. Menurut Mulyasa (2020) bahwa "Kreativitas ditandai oleh adanya kegiatan menciptakan sesuatu yang sebelumnya tidak ada dan tidak dilakukan oleh seseorang atau adanya kecenderungan untuk menciptakan sesuatu" (h. 51). Berpikir kreatif membantu untuk memfokuskan tujuan, ide-ide, serta kemungkinan lain dengan mencari alternatif yang mendukung terbentuknya kreativitas pada seseorang (Apriza \& Mahendra, 2021). Muslimin, Amran, \& Hafid (2019) mengatakan bahwa guru berperan sebagai fasilitator untuk mendorong siswa berinteraksi dengan kegiatan pembelajaran yang menarik dan lingkungan sekitar pembelajaran yang kondusif dan efektif.

Kreativitas guru merupakan proses atau kegiatan yang dilakukan oleh seseorang atau guru untuk menciptakan atau membuat hal-hal baru dan berbeda yang belum dan tidak ada sebelumnya yang melahirkan gagasan, proses, metode maupun produk untuk menstimulus siswa dalam belajar yang berpengaruh terhadap motivasi, minat serta prestasi. Menurut Rasam \& Sari (2018) bahwa" kreativitas guru akan membantu dalam penyampaian materi pelajaran kepada siswa sehingga proses pembelajaran dalam kelas akan terasa tertantang, menarik dan tidak jenuh" (h. 97). Tidak hanya itu, kreativitas guru tersebutlah yang menjadi strategi agar siswa terlibat aktif dalam pembelajaran agar tujuan pembelajaran mencapai keberhasilan yang maksimal. Pada dasarnya, guru yang kreatif dalam proses pembelajaran merupakan wujud yang mampu menarik perhatian siswa melalui perubahan tingkah laku siswa selama belajar di kelas.

Minat belajar sangat dibutuhkan dalam proses pembelajaran, sehingga siswa dapat memahami materi pelajaran dengan baik. Adapun menurut Gie (2000), minat adalah kegiatan yang menarik perhatian, memudahkan terciptanya konsentrasi, mencegah gangguan dari luar, memperkuat melekatnya bahan pelajaran yang bermakna dalam ingatan dan memperkecil kebosanan belajar dalam diri sendiri (Satriani, 2021, h.93). Jadi, dapat dipahami bahwa minat adalah usaha yang ditunjukkan ke arah positif melalui ketertarikan yang dimiliki.

Beberapa aspek-aspek minat belajar menjadi sebab individu memiliki ketertarikan untuk melakukan sesuatu yang diminatinya. Aspek-aspek tersebut 
dapat menjadi pertimbangan bagi guru untuk menciptakan suasana belajar yang dapat menstimulus siswa untuk belajar. Djaali (2013) mengemukakan bahwa aspek-aspek minat belajar adalah perasaan senang, keterlibatan siswa, ketertarikan, dan perhatian siswa.

Faktor-faktor yang mempengaruhi minat belajar menurut Rusman (2017) diuraikan yaitu: 1) Faktor internal. a) Faktor fisiologis seperti kondisi kesehatan yang prima, tidak dalam keadaan lelah dan capek, tidak dalam keadaan cacat jasmani, dan sebagainya. Hal-hal tersebut dapat mempengaruhi siswa dalam menerima materi pelajaran. b) Faktor psikologi merupakan kondisi individu dalam hal ini siwa yang pada dasarnya memiliki kondisi psikologis yang berbeda-beda, tentunya hal ini turut mempengaruhi belajarnya. Beberapa faktor psikologi, meliputi inteligensi (IQ), perhatian, minat, bakat, motif, motivasi, kognitif, dan daya nalar siswa. 2) Faktor eksternal. a) Faktor lingkungan meliputi lingkungan fisik dan lingkungan sosial. b)
Faktor lingkungan instrumental adalah faktor yang keberadaan dan penggunaannya dirancang sesuai dengan hasil belajar yang diharapkan. Faktor-faktor instrumental ini berupa kurikulum, sarana, dan guru (h. 131). Tinggi rendahnya minat belajar siswa dipengaruhi oleh tingkat kreativitas guru. Jadi, dapat dipahami bahwa kreativitas guru secara langsung dapat mempengaruhi minat belajar siswa yang timbul melalui proses pembelajaran.

Hasil penelitian diperoleh dari hasil perhitungan angket kreativitas guru dan minat belajar siswa kelas V SD Gugus III.

Berdasarkan data dari angket pelaksanaan kreativitas guru kelas V SD Gugus III yang diperoleh skor tertinggi = 119 dan skor terendah sebesar $=65$, ratarata $($ mean $)=97,70$, median $=99$, modus sebesar = 99 dan standar deviasi yaitu 10,352 .

Berdasarkan analisis di atas maka diperoleh tabel pengkategorian nilai kreativitas guru sebagai berikut:

Tabel 1: Kategorian Kreativitas Guru Kelas V SD Gugus II

\begin{tabular}{cccc}
\hline Nilai & \multicolumn{2}{c}{ Frekuensi } & \multirow{2}{*}{ Kategori } \\
\cline { 2 - 3 } Interval & Frekuensi & $\%$ & \\
\hline $108>\mathrm{X}$ & 21 & $18 \%$ & Tinggi \\
\hline $87<\mathrm{X} \leq 108$ & 78 & $65 \%$ & Sedang \\
\hline 87 & 20 & $17 \%$ & Kurang \\
\hline Total & 120 & $100 \%$ & \\
\hline
\end{tabular}

Sumber: Hasil Angket Penelitian, 2021 
Hasil dari pengkategorian yang terdapat pada tabel 1. diketahui bahwa 21 siswa memiliki nilai angket yang berada pada kategori tinggi dengan persentase sebesar 18\%. Sebanyak 78 siswa memiliki nilai angket yang berada pada kategori sedang dengan persentase sebesar $65 \%$ dan sebanyak 20 siswa memiliki nilai angket yang berada pada kategori kurang dengan persentase sebesar $17 \%$.

Berdasarkan data dari angket diperoleh tabel pengkategorian nilai pelaksanaan minat belajar siswa kelas $\mathrm{V}$ kreativitas guru sebagai berikut: SD Gugus III yang diperoleh, selanjutya

data tersebut dianalisis menggunakan bantuan SPSS versi 25. Berdasarkan hasil olah data yang dianalisis menggunakan mean, median, modus dan standar deviasi menggunakan bantuan SPSS versi 25. Diperoleh skor tertinggi $=$ 119 dan skor terendah sebesar $=67$, ratarata $($ mean $)=99,60$, median $=100$, modus sebesar $=99$ dan standar deviasi yaitu 10.764 .

Berdasarkan analisis di atas maka Tabel 2: Nilai Kreativitas Guru

\begin{tabular}{cccc}
\hline Nilai & \multicolumn{2}{c}{ Frekuensi } & \multirow{2}{*}{ Kategori } \\
\cline { 2 - 3 } Interval & Frekuensi & $\%$ & \\
\hline $110>\mathrm{X}$ & 21 & $18 \%$ & Tinggi \\
\hline $89<\mathrm{X} \leq 110$ & 79 & $66 \%$ & Sedang \\
\hline 89 & 19 & $16 \%$ & Kurang \\
\hline Total & 120 & $100 \%$ & \\
\hline
\end{tabular}

Sumber: Hasil Angket Penelitian, 2021

Hasil dari pengkategorian yang Hasil Uji normalitas dimaksudkan terdapat pada tabel 2 diketahui bahwa 21 siswa memiliki nilai angket yang berada pada kategori tinggi dengan persentase sebesar 18\%. Sebanyak 79 siswa memiliki nilai angket yang berada pada kategori sedang dengan persentase sebesar $66 \%$ dan sebanyak 19 siswa memiliki nilai angket yang berada pada kategori kurang dengan persentase sebesar $16 \%$. untuk mengetahui data yang diteliti berdistribusi normal atau tidak. Dari hasil tersebut terlihat bahwa kedua variabel uji normalitas $P$-Value lebih besar dari $\alpha=$ 0,05 . Skor kreativitas guru pada nilai Nilai Asymp. Sig. (2-tailed) P-Value 0,200 dan skor minat belajar pada nilai Nilai Asymp. Sig. (2-tailed) P-Value 0,010. Sehingga data kedua variabel tersebut berdistribusi normal. 
Uji hipotesis dengan moment dengan langkah-langkah menggunakan analisis korelasi product sebagai berikut: Menghitung nilai

korelasi dengan memakai rumus terdapat pengaruh kreativitas guru korelasi product moment. Hasil yang sebesar 19,62\% terhadap minat belajar. diperoleh nilai koefisien korelasi sebesar 0,443 dengan nilai signifikansi 0,000 karena nilai signifikansi $<0,05$ maka terdapat hubungan yang signifikan. Berdasarkan dasar pengambilan keputusan: jika nilai person correlation > rtabel artinya terdapat hubungan, sebaliknya jika nilai person correlation < $r_{\text {tabel }}$ artinya tidak terdapat hubungan. $r_{\text {tabel }}$ pada N 120 ialah 0,177 dengan taraf kepercayaan 5\%, jika nilai koefisien korelasi sebesar 0,443 berarti nilai $r_{\text {hitung }} \geq$ $r_{\text {tabel }}(0,443 \geq 0,177)$, sehingga Ho ditolak dan $\mathrm{Ha}$ diterima. Artinya terdapat hubungan yang signifikan antara kreativitas guru dan minat belajar.

Untuk mengetahui seberapa besar pengaruh antara variabel $(\mathrm{X})$ terhadap variabel $(Y)$ dilakukan uji koefisien determinasi. Hasil pengujian dapat dilihat pada tabel sebagai berikut:

$$
\begin{aligned}
\mathrm{KP} & =r^{2} \times 100 \% \\
& =\left(0,443^{2}\right) \times 100 \% \\
& =0,196249 \times 100 \% \\
& =0,196249 \% \\
& =19,62 \%
\end{aligned}
$$

Dari koefisien determinasi diperoleh sebesar 19,62 \%. Artinya Hasil analisis statistik deskriptif yang memberikan gambaran tentang kreativitas guru dengan minat belajar kelas V SD Gugus III Kecamatan Tanette Riattang Kabupaten Bone kategori sedang. Hasil tersebut diharapkan dapat dijadikan pedoman bagi guru untuk dapat meningkatkan lagi keterampilan kreativitas guru dalam pembelajaran

Melalui kreativitas guru proses pembelajaran perlu penguasaan terhadap komponen pembelajaran, maka setiap komponen pembelajaran dapat ditingkatkan melalui guru kreatif pada setiap proses pembelajaran. Sejalan dengan hal itu, Talajan (2012) mengemukakan komponen pembelajaran di kelas yang dapat meningkatkan kreativitas guru

Siswa yang memiliki minat belajar akan mencurahkan segenap waktunya untuk belajar perihal yang diinginkan. Sebaliknya, siswa yang memiliki minat belajar rendah akan bersikap acuh terhadap belajar sehingga akan sulit untuk mencapai keberhasilan dalam belajarnya. Sejalan dengan hal itu, Rusman (2017) mengatakan faktor yang mempengaruhi minat belajar karena dua 
faktor yaitu faktor internal dan faktor eksternal. Dengan demikian, untuk meningkatkan minat siswa dalam belajar perlunya peran guru pada faktor eksternal Berdasarkan hasil statistik menunjukkan bahwa $r_{\text {hitung }}$ sebesar 0,443 sedangkan $r_{\text {tabel }}$ pada taraf signifikansi $5 \%$ sebesar 0,177 sehingga $r_{\text {hitung }} \geq r_{\text {tabel }}(0,443 \geq 0,177)$. Jadi dapat ditarik sebuah kesimpulan bahwa "Terdapat hubungan yang signifikan antara kreativitas guru dengan minat belajar ". Sedangkan untuk mengetahui besarnya tingkat hubungan antar variabel maka dilakukan interpretasi terhadap koefisien korelasi.

Mengacu pada rhitung dari hasil perhitungan yang telah dilakukan dan tabel interpretasi koefisien korelasi, maka diperoleh hasil bahwa tingkat hubungan kedua variabel tersebut tergolong sedang panda rentang 0,40 - 0,599. Hasil analisis penelitian menunjukkan ada hubungan antara kreativitas guru dengan minat belajar siswa. Uraian dijelaskan bahwa kreativitas guru berkontribusi sebesar 19,62\%, dalam menumbuhkan minat belajar siswa, sedangkan $80,38 \%$ lainnya dipengaruhi oleh faktor lain yang tidak diteliti.

Hasil tersebut menunjukkan bahwa kreativitas guru mampu akan mampu membangkitkan minat belajar karena bertujuan menarik ketertarikan, perasaan senang, keterlibatan, dan perhatian siswa dalam proses pembelajaran.

\section{Kesimpulan}

Berdasarkan rumusan masalah dan hasil penelitian, maka dapat dikemukakan kesimpulan peneliti sebagai berikut bahwaKreativitas guru kelas V SD Gugus III Kecamatan Tanette Riattang Kabupaten Bone memiliki nilai rata-rata sebesar 97,70 dan nilai persentase kategorisasi kreativitas guru sebesar $65 \%$ yang berada pada kategori sedang, Minat belajar siswa kelas V SD Gugus III Kecamatan Tanette Riattang Kabupaten Bone memperoleh nilai rata-rata sebesar 99,60 dan dan nilai persentase kategorisasi kreativitas guru sebesar $66 \%$ yang berada pada kategori sedang. Dan Terdapat hubungan yang signifikan antara kreativitas guru dengan minat belajar siswa kelas tinggi kelas $\mathrm{V} S \mathrm{SD}$ Gugus III Kecamatan Tanette Riattang Kabupaten Bone. Hal ini dapat dibuktikan dari hasil analisis data dengan menggunakan rumus korelasi produc moment pada rabel yaitu 0,177 dengan taraf kepercayaan $5 \%$, jika nilai koefisien korelasi sebesar 0,443 berarti nilai $r_{\text {hitung }} \geq$ $r_{\text {tabel }}(0,443 \geq 0,177)$, sehingga terdapat hubungan yang signifikan antara 
kreativitas guru dan minat belajar. meningkatkan minat belajar siswa, Terdapat pengaruh kreativitas guru hendaknya kegiatan siswa selama proses dengan minat belajar siswa dengan pembelajaran dilaksanakan dengan menunjukan hasil yang signifikan sebesar pembelajaran yang menarik, inovatif, 19,62 \%. Berdasarkan uraian simpulan kreatif, dan melibatkan siswa secara penelitian di atas, peneliti memberikan langsung dalam kegiatan pembelajaran beberapa saran yaitu Guru diharapkan tersebut dan Peneliti yang minat mengkaji dapat meningkatkan keterampilan masalah yang relevan dengan penelitian kreativitas guru agar dapat ini diharapkan dapat mengembangkan mengembangkan kemampuannya dalam penelitian ini sehingga dapat menambah mengajar sehingga dapat mencapai wawasan serta kontribusi yang diberikan tujuan pembelajaran serta dapat menarik untuk minat belajar siswa pada proses minat siswa dalam belajar. Untuk pembelajaran.

\section{Daftar Pustaka}

Aldizar, A. (2017). Membangun Guru Kreatif. Surakarta: Sinergi Prima Magna.

Apriza, B., \& Mahendra, Y. (2021). Efektivitas Pendekatan CTL Dan Discovery Terhadap Kemampuan Berpikir Kreatif Dalam Pemecahan Masalah Mahasiswa PGSD UMKO. JIKAP PGSD : Jurnal IImiah IImu Kependidikan, 5(1), 9.

Arifi, A., Sabarudin, \& Machali, I. (2017). Mengembangkan Potensi Melejitkan Kreativitas Guru. Yogyakarta: Universitas Islam Negeri Sunan Kalijaga.

Dzaki, K. F. (2018). Hubungan Kreativitas Guru Dalam Menggunakan Media Pembelajaran Dengan Minat Belajar Siswa Pada Mata Pelajaran Fikih Kelas Viii Di Mts Tarbiyah Islamiah Hinai Kiri Kec. Secanggang Kab. Langkat. .

Kemindikbud, Sim. (2003). Undang-Undang Republik Indonesia No 20 Tentang Sistem Pendidikan Nasional (Patent No. 20). In Jakarta: Direktorat Pendidikan Menengah Umum (No. 20). http://stpi-binainsanmulia.ac.id/wpcontent/uploads/2013/04/Lamp_2_UU20-2003-Sisdiknas.doc

Mulyasa, E. (2020). Menjadi Guru Profesional Menciptakan Pembelajaran Kreatif dan Menyenangkan. Bandung: PT. Remaja Rosdakarya.

Muslimin, Amran, M., \& Hafid, A. (2019). Developing Project-Based Learning Tools For Science By Utilizing Used Materials. 11(08), 1271-1280.

Nimury, R. (2019). Pengaruh kreativitas guru terhadap minat belajar siswa pada mata pelajaran ekonomi di sekolah menengah atas negeri 14 pekanbaru. Universitas Islam Negeri Sultan Syarif Kasim Riau. 
Noviantari, N. (2017). Pengaruh Kreativitas guru Terhadap Minat Belajar Siswa Di SD Muhammadiyah 09 Malang. Universitas Islam Negeri Maulana Malik Ibrahim Malang.

Nurhaeda, R. (2020). Pengaruh Kreativitas Guru dan Minat Belajar Siswa terhadap Hasil Belajar Siswa Kelas VII pada Mata Pelajaran IPS di MTsN 1 Pasuruan. Universitas Islam Negeri Maulana Malik Ibrahim.

Nurjan, S. (2016). Psikologi Belajar . Ponorogo: Wade Group.

Rasam, F., \& Sari, A. I. C. (2018). Peran Kreativitas Guru Dalam Penggunaan Media Belajar Dan Minat Belajar Dalam Meningkatkan Prestasi Belajar Peserta Didik Smk Di Jakarta Selatan. Research and Development Journal Of Education, 5(1), 95-113.

Rusman. (2017). Belajar dan Pembelajaran Berorientasi Standar Proses Pendidikan. Jakarta: PT Kharisma Putra Utama.

Satriani. (2021). Hubungan Antara Minat Baca Terhadap Kemampuan Membaca Pemahaman Siswa Kelas V SD Gugus I Kecamatan Ulaweng. JIKAP PGSD: Jurnal IImiah IImu Kependidikan, 5(1), 92-97.

Sugiyono. (2020). Metode Penelitian Kuantitatif dan Kualitatif, dan $R \& D$. Bandung: Alfabeta.

Supardi. (2017). Statistik Penelitian Pendidikan. Depok: PT RAJAGRAFINDO PERSADA.

Suprihatiningrum, J. (2014). Guru Profesional: Pedoman Kinerja, Kualifikasi dan Kompetensi Guru (R. Kusumaning Ratri (ed.)). Ar- Ruzz Media.

Uno, H. B., \& Mohamad, N. (2011). Belajar dengan Pendekatan PAIKEM: Pembelajaran Aktif, Inovatif, Lingkungan, Kreatif, Efektif, Menarik. Jakarta: Bumi Aksara.

Wilda, Salwah, \& Ekawati, S. (2017). Pengaruh kreativitas dan minat belajar terhadap hasil belajar matematika siswa. Jurnal Pendidikan Matematika, 2(1), 134-144. 